\title{
Genetic material
}

INSERM

\section{Source}

INSERM. (1999). Orphanet: an online rare disease and orphan drug data base. Genetic material. ORPHA:C010

DNA or RNA sequence (gene with protein product, non-coding RNA and disorderassociated locus). 